\title{
MODEL PENCEKRAM BEBAN PINTAR METODA ELEKTROMAGNETIK
}

\author{
JAJAT YUDA MINDARA*, LIU KIN MEN, SETIANTO, SAHRUL HIDAYAT \\ Departemen Fisika Fakultas MIPA, Universitas Padjadjaran \\ Jalan Raya Bandung-Sumedang KM.21 Jatinangor 45363 \\ "e-mail:jajat@phys.unpad.ac.id
}

\begin{abstract}
Abstrak. Kecakapan robot tergantung pada piranti yang dipasang pada lengan robot yang disebut end effector. Ada dua jenis end effector yaitu Peralatan (Tools) dan Pencengkram (Gripper), umumnya robot yang digunakan pada bidang industri menggunakan kedua jenis tersebut. Contoh untuk Tools. digunakan untuk melakukan operasi pada suatu objek, contohnya bor, penyemprot cat, gerinda, alat las, dan banyak lainnya. Jenis Gripper yaitu suatu piranti yang dapat digunakan untuk memegang atau mencekram sebuah objek, contohnya tangan mekanik dan piranti pengait dengan metoda elektromagnetik atau metoda hisap.Pencekram metoda elektromagnetik dapat digunakan untuk mengangkat objek bahan logam khusunya besi. Pencekram ini pada prinsinya menggunakan hukum Biot savart, yaitu medan magnet pada lilitan kawat yang ditimbulkan akibat arus listrik. Model pencekram beban pintar yang didesain dimana pemberian arus berdasarkan beban terangkat, dengan peraba terang atau gelap menggunakan piranti Light Dependence Resistor (LDR).
\end{abstract}

Kata kunci: End Effector, Tools, Gripper, LDR, Biot Savart.

\begin{abstract}
Skills of robot depends on the device which is mounted on a robotic arm that called end effector. There are two types of end effector that is tools and gripper, generally robot used in industrial fields using both of types. Examples for tools, used to perform operations on an object, for example in a drill, paint sprayers, grinding, welding tools, and many others. Gripper type is a device that can be used to hold or grip an object, for example a mechanical hand and hook devices with electromagnetic method or suction method. Gripper with electromagnetic method can be used for lifting an metal objects especially iron. This method used the Biot-Savart law that the magnetic field in the coils caused by electric current.Model of gripper smart load is designed with current based on a load lifted, by the light or dark probe of Light Dependence Resistor (LDR).
\end{abstract}

Keywords: End Effector, Tools, Gripper, LDR, Biot Savart.

\section{Pendahuluan}

Dewasa ini teknologi robotik pada bidang industri telah berkembang pesat dan sangat diperlukan untuk mengatasi pekerjaan yang berbahaya, rutin dan sukar bila dilakukan oleh tangan manusia[1]. Sistem robot pengangkat beban umumnya terdiri atas: end effector yaitu sebagai telapak tangan pada lengan, peraba beban dan bagian pengaturannya. Pada prinsipnya ada dua jenis end effector. Pertama adalah pencekram (gripper) yaitu piranti yang dapat digunakan untuk memegang atau mencekram sebuah objek, dengan metoda mekanik, metoda elektromagnetik atau metoda penghisap. Jenis kedua adalah peralatan (tools), yaitu piranti yang digunakan robot untuk melakukan operasi pada suatu objek. Contohnya adalah bor, penyemprot cat, gerinda, alat las, dan yang lainnya. End effector pencekram elektromagnetik umumnya digunakan untuk mengangkat beban bahan logam besi, pada prinsipnya berdasarkan hukum Biot Savart yaitu medan magnet pada lilitan 
kawat yang ditimbulkan akibat arus listrik $[2,3,4]$. Umumnya yang ada di industri, untuk setiap beban, medan magnet yang dihasilkan dengan menggunakan arus tetap tertentu. Hal ini tidak efisien pada sumber arusnya. Alternatifnya menggunakan pengaturan arus berdasarkan beban yang diangkat. Dalam pkm ini dibahas desain model End Effector Grip Electromagnetic [5]untuk pencekram beban dimana pemberian arus berdasarkan beban terangkat dengan peraba Light Dependence Resistor.

Berdasarkan latar belakang, perumusan masalah dalam desain model pencekram beban pinter metoda elektromagnetik adalah sebagai berikut:Bagaimana merumuskan dan memilih parameter desain hubungan antara besar medan magnet terhadap beban yang mampu diangkat, bagaimana mendesain pengontrolan sensor dan aktuator keberadaan beban yang mampu dicekram terangkat, serta bagaimana desain perantara (I/O) dan ADC untuk proses antarmuka ke komputer serta prosedur perangkat lunaknya.

Tujuannya mengembangkan sistem end effector lengan robot industri, maksudnya desain perangkat keras dan perangkat lunak untuk model End Effector Grip Elektromagnetik untuk pencekram beban dimana pemberian arus berdasarkan beban terangkat dengan peraba Light Dependence Resistor. Model yang dirancang untuk beban ringan plat besi ringan. Sesuai dengan tujuan program, langkahnya adalah: merumuskan dan mendesain perangkat keras [6]. Luaran akan didapat Prosedur desain, Prosedur perangkat lunak mixing dan pemrosesan pengontrolan pencekram Dan Prototipe perangkat keras model pencekram beban pintar. Diharapkan hasil pengembangannya didapat suatu model pencekram beban pintar untuk keperluan industri

\section{Metode Pendekatan}

Metode yang digunakan adalah eksperimen dengan tahapan sebagai berikut: Studi liteatur dan observasi mengenai Robot dan otomasi industri, Arm dan End Effector, transducer potensiometrik, pengkondisi sinyal, akuisisi data, pemrograman dan lainnya untuk keperluan desain. Selanjutnya mendeskripsikan diagram blok sistem, prinsip kerja, merumuskan implementasi hukum Biot Savart khususnya hubungan arus terhadap medan magnet, rumusan empirik medan magnet terhadap beban, transformasi dan konversi data sudut dan intensitas, algoritma pemrograman[7]. Langkah ini perlu dilakukan karena proses pengontrolan menggunakan komputer. Kemudian berdasarkan deskripsi, didesain perangkat keras meliputi konstruksi untuk elektromagnetik, pengkondisi sinyal, kontruksi motor, pengkondisi sinyal, dan perantara ADC sebagai subsistem pengkonversi data analog ke digital. Kemudian didesain perangkat lunak meliputi algoritma, pengaksesan gerak manual dan gerak rutin. Selanjutnya disusun kebutuhan komponen, peralatan, prosedur pengujian masing-masing subsistem dan integrasi. Proses perbaikan dilakukan untuk mendapatkan hasil yang sesuai dengan perumusan desain..

Berdasarkan dengan metoda pelaksanaan desain sistem meliputi desain model sistem yang diusulkan pengangkat beban pintar metoda elektromagnetik, diagram blok sistem ditunjukkan Gambar 1. terdiri atas: Subkontruksi pengangkat beban dengan spesifikasi terdiri dari satu lengan dengan tiga poros gerak satu end 
effector grip elektromagnetik. Subbagian transducer tiga sudut poros gerak dan sensor cahaya serta pengkondisi sinyalnya. Perantara ADC sebagai pengkonversi sudut dan intensitas ke data digital. Perantara DAC dan penguat arus untuk pemberi variabel arus pada induktor. Induktor untuk sumber elektromagnetik. Driver motor penggerak poros lengan. Perantara (I/O) untuk ADC, DAC dan Driver motor. Komputer dan perangkat lunaknya berfungsi untuk proses pengontrolan untuk menu manual dan automatik (gerak-gerak rutin tertentu).

Untuk model pencekram beban pintar yang diusulkan, dapat diprogram untuk suatu program gerak rutin. Misal untuk melakukan pemindahan benda dari posisi1 ke posisi-2, dengan berat beban tertentu. Dari posisi awal lengan akan bergerak ke posisi-1 sampai end effector grip menyentuh benda yang akan diangkat, selanjutnya sesuai program akan menset skala arus pada arus-1, yang akan menghasilkan elektromagnetik ke-1, saat itu grip akan mencekram beban, sensor cahaya bekerja, bila ketika lengan akan bergerak

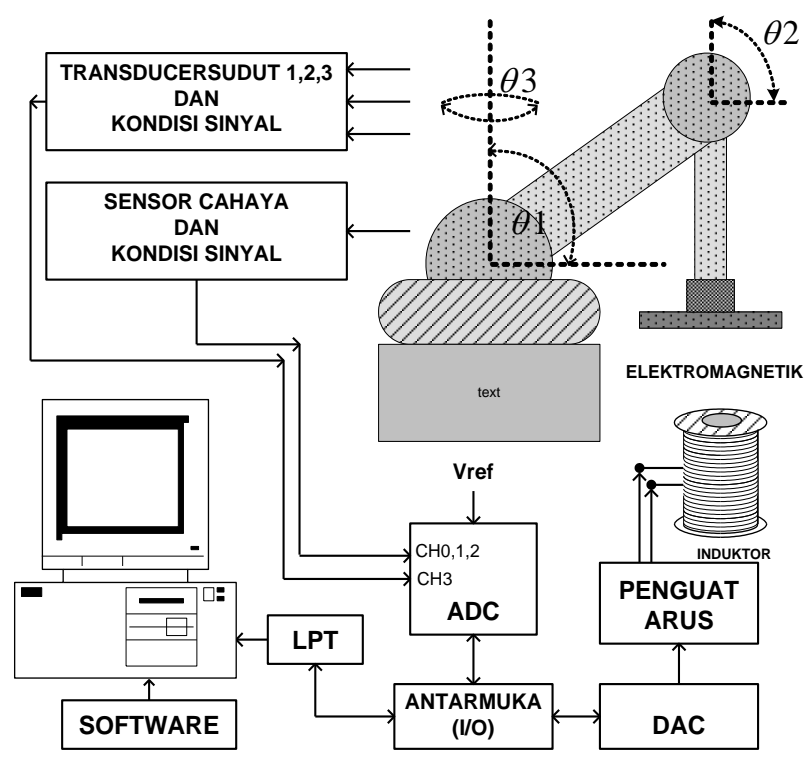

\section{Gambar 1 Diagram Blok Sistem Pencekram Beban Pinter Metoda Elektromagnetik.}

ke posisi-2, beban jatuh artinya tidak terangkat, sensor cahaya bekerja, untuk mematikan sumber arus-1, lengan kembali ke posisi-1 sampai menyentuh beban yang akan diangkat, dan menset arus pada skala arus-2, yang menghasilkan elektromagnetik-2., selanjutnya mencekram beban, bila kondisi terangkat, lengan akan memindahkan beban pada posisi-ke-2, mematikan arus dan kembali ke posisi-1 untuk mengambil beban selanjutnya, sampai beban terakhir.

Skematik Perangkat Keras Sistem Pencekram Beban Pinter ditunjukkan Gambar 2, terdiri atas Rangkaian Transducer Sudut dan Cahaya. Perantara ADC dan DAC serta Penguat Arus, Driver Motor DC. Perantara (I/O) akses LPT dan Catu Daya. Rangkaian pengkondisi sinyal sudut ditunjukkan Gambar 2, dengan transducer potensiometrik Wireworm, rangkaian jembatan dan penguat operasional.

Sesuai tinjauan pustaka End effector Gripper elektromagnetik bekerja berdasarkan hukum Biot Savart, yaitu diperlukan sumber arus untuk menghasilkan medan 
magnet, pada lilitan kawat (coil) yang diletakkan core dari bahan logam ferromagnetik, untuk untuk menghilangkan medan magnet tinggal memutuskan arus yang terhubung. Jenis beban dengan gripper elektromagnetik ini adalah material logam atau baja dalam bentuk apapun, dalam desain untuk bentuk pelatpelat baja tipis. Sesuai tinjauan pustaka bahan inti induktor yang bisa dimagnetisasi disebut ferromagnetik, termasuk diantaranya nikel, kobalt, dan besi (baja mengandung lebih dari $99 \%$ besi). Beberapa logam lain yang tidak terpengaruhi oleh magnet antara lain tembaga, aluminium, timah dan seng. Untuk menghasilkan efek yang maksimum, seluruh permukaan magnet haruslah bersentuhan dengan permukaan logam yang akan di cengkram. Adanya lapisan udara kan mengurangi kekuatan tenaga magnetnya. Dengan demikian, lembaran logam yang rata merupakan pencengkeram magnetik yang paling tepat, meskipun masih mungkin untuk mengambil objek yang memiliki permukaan yang tidak beraturan apabila magnetnya cukup kuat.

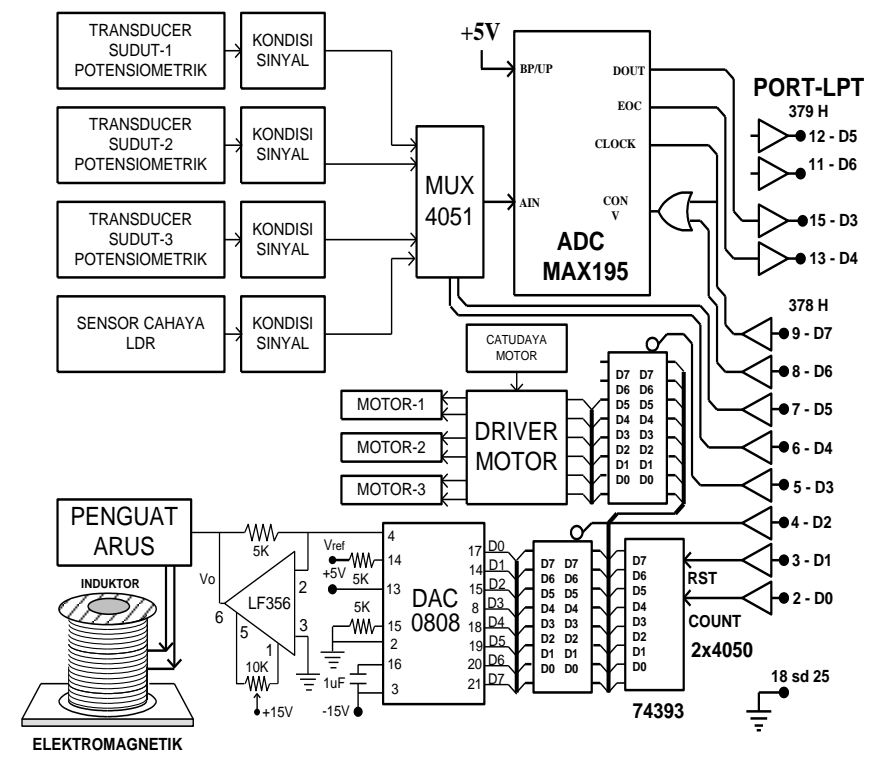

Gambar 2 Skematik Perangkat Keras Sistem Pencekram Beban Pintar

Persamaan emperik untuk berat beban terhadap medan magnet adalah,

$\Phi=K_{m} \frac{\mu_{o} \cdot N \cdot A .}{L} . I$

Dimana fluks ini menyatakan kekuatan magnet bergantung dimensi dan arus listrik lilitan. Misal dalam daerah elektromagnetik yang tidak jenuh, hubungannya kuat medan terhadap beban secara empirik dapat dinyatakan dengan,

Berat $=\alpha . \Phi$

Dimana $\alpha$ adalah konstanta pembanding, dapat ditentukan dari eksperimen. Dari kedua persamaan diatas dapat dirumuskan Berat terhadap berubahan arus untuk geometri pencekram tertentu yaitu, 
Berat $=\alpha \frac{K_{m} \mu_{0} \cdot N \cdot A .}{L} . I$

Dari persamaan diatas dengan ditentukan Geometri dan bahan inti coil yaitu, Jumlah lilitan (N), panjang lilitan (L), Luas penampang inti (A) dan bahan permeabilitas inti $\left(\mathrm{K}_{\mathrm{m}} \mu_{\mathrm{o}}\right)$ maka akan didapat hubungan Berat terhadap perubahan arus (I). Untuk kontruksinya sesuai skematik Gambar 3.

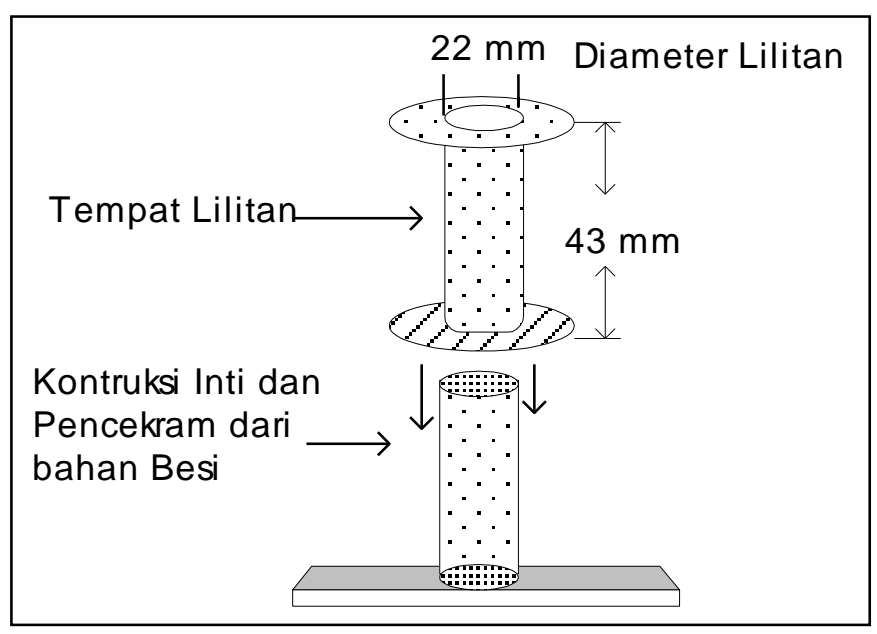

Gambar 3 Konstruksi Induktor Dan Pencekram

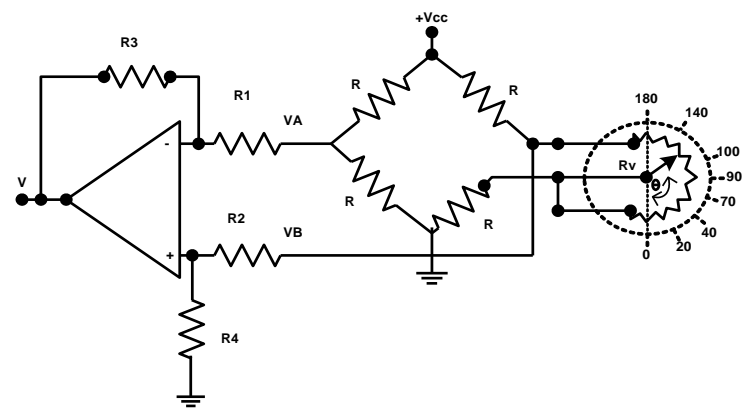

Gambar 4 Pengkondisi Sinyal Transducer Sudut

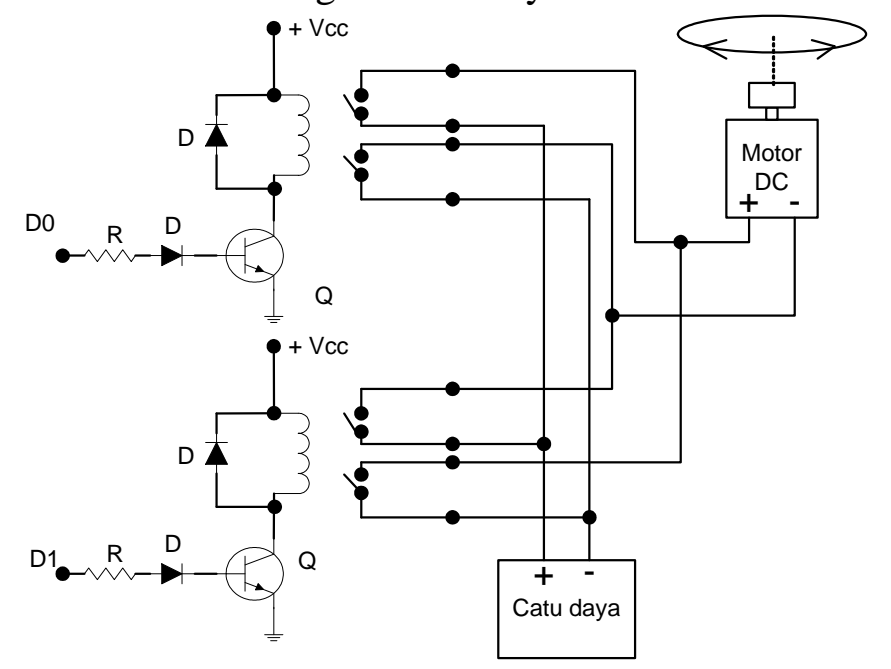

Gambar 6. Driver Motor DC 
Ada beberapa hal yang menjadi aspek perancangan suatu rangkaian elektromagnetik yaitu coil dan inti (core). Untuk Coil, yang perlu diperhatikan adalah : Diameter, Panjang lilitan coil dan Jumlah lilitan kawat pada core.

Untuk Inti (Core) yang perlu diperhatikan adalah : Ukuran dari core, Jenis bahan apa yang digunakan sebagai core, udara atau bahan logam. Jika inti berupa logam bisa berlapis atau solid. Bentuk dari core tersebut sesuai dengan bentuk beban.

Semua hal tersebut mempengaruhi kekuatan elektromagnetik. Sebab satu item diatas mempunyai efek paling besar yang disebut ampere-turns/meter (Magnetizing Force) pada solenoida. Ini sederhananya banyaknya ampere mengalirkan arus dalam kawat pada coil dikalikan dengan banyaknya putaran kawat pada sekitar core sepanjang jarak coil. Maka, panjangnya kawat, diameter kawat, jumlah lilitan dan sumber arus mempengaruhi nilai ampere yang akan mengalir atau banyaknya putaran, baik itu salah satu atau kedua-duanya.

Kawat yang digunakan untuk coil ini mempunyai panjang lilitan $43 \mathrm{~mm}=0.043$ $\mathrm{m}$, diameter $22 \mathrm{~mm}=0.022 \mathrm{~m}$, Jumlah lilitan yang digunakan sebanyak $\mathrm{N}=500$ lilitan. Bentuk rangkaian coil terhadap core berbentuk silinder, ditunjukkan Gambar 3.2, untuk mendekati harga medan magnet solenoida maksimum. Bahan coil berupa plastik untuk menghindari pembentukan medan magnet pada coil, agar medan magnet yang diberikan pada core maksimum. Core berupa bahan logam solid dengan nilai permeabilitas relatip 1000 kali dari permeabilitas udara. Bahan core yang dipakai untuk pengujian termasuk logam ferromagnetik. Permukaan core sebagai permukaan yang bersentuhan dengan obyek, berupa ujung baut pada core yang berbentuk lingkaran, dengan luas $\mathrm{A}=0,00076 \mathrm{~m}^{2}$.

Untuk pergerakan poros lengan menggerakan Motor DC dan kontruksi gigi, dengan driver Ditunjukkan pada Gambar 6. Rangkaian driver pada prinsipnya adalah untuk memutuskan arus dari sumber tegangan ke lilitan motor. Dalam desain digunakan rangkaian swit transistor, yang pada prinsipnya kerja transistor diubah dari keadaan cut-off (tidak ada tegangan) ke keadaan saturasi (ada tegangan).

Pengkondisian sudut ke tegangan dapat dirumuskan dengan,

$V=\left(\frac{R 3}{R 4}\right) \cdot\left(\frac{V C C}{4 R}\right) \cdot K 1 \cdot \theta$

Sesuai tinjauan pustaka, dengan ADC modus Bipolar 16 bit, Vref $(0,5)$ Volt, Perumusaan Transformasi dan konversi sudut-1,2,3 sama untuk rotasi 180 Derajat.

Data $=\left(\frac{65535}{180}\right) \cdot \theta$

Dan untuk intensitas cahaya, dengan transducer LDR dengan cara pengkondisian yang sama, hubungan data terhadap intensitas didesain,

Data $=\left(\frac{65535}{1000}\right) \Omega$

Dimana Data adalah variabel Data Word, $\theta$ dalam derajat sudut, $\Omega$ dalam Lumen. Catu daya merupakan bagian yang berfungsi untuk menyediakan daya untuk daya rangkaian. Dalam desain catu daya, yaitu catu daya untuk Perantara ADC dengan Catu $-5,0,+5$ Volt, DAC derngan Catu $(0,5,-15,0,+15)$ Volt, Pengkondisi sinyal 
transducer $-15,0,+15)$ Volt Catu daya motor $(0,12)$ Volt. Dalam desain menggunakan rangkaian jembatan dioda dan filter kapasitor dengan regulator tegangan tetap adalah LM78xx, 79xx.

\section{Perangkat Lunak}

Perantara ADC untuk perantara sudut dan intensitas ke data word digunakan ADC Maxim 195 yang diakses melalui port standard LPT IBM PC pengaksesan melalui alamat (I/O) $378 \mathrm{H}$ dan 379H. Dengan Algoritma pengkonversian data mengikuti urutan instruksi: Start konversi, Baca end konversi, Ambil data serial 16 bit, Ubah ke data word, Ubah ke tegangan, Ubah ke sudut atau intensitas cahaya adalah sebagai berikut:

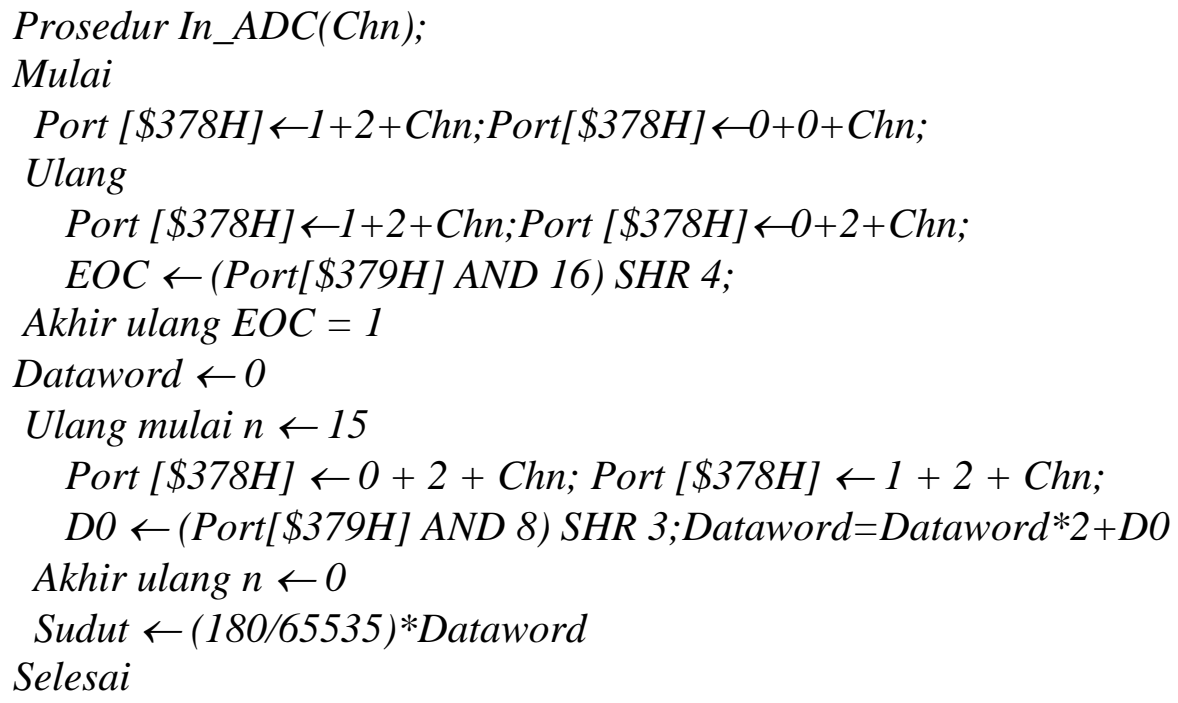

Perantara DAC untuk konversi Data ke arus digunakan DAC0808 diakses melalui port LPT IBM PC pengaksesan melalui Pencacah 74393 dan Latch 74273, dengan alamat (I/O) 378H. Dalam desain hubungan arus terhadap Databyte, dengan pengkondisian penguat arus pada tegangan tetap 30 Volt, yaitu

$$
\text { Io }=\left(\frac{1}{51}\right) \text {.DataByte }
$$

DataByte dapat berubah dari (0 sd 255), arus Io dalam Ampere. Prosedur Pascal untuk mengeluarkan Databyte mengikuti urutan instruksi,

Uses crt;

Const Count $=1 ; R s t=2 ; L 1=4 ; L 2=8 ; ;$ Latch $=L 1+L 2+L 3+L 4+L 5+L 6$;

Var j,i,ii,cnt:byte;

Procedure Resset; Begin Port [\$378]:=Rst+Count+Latch;End;

Procedure Keluar(L,Cnt:byte);

Begin

Resset;

For ii:=0 to Cnt do Begin Port[\$378]:=Latch;Port[\$378]:=Count+Latch;End;

Port [\$378]:=(Count+Latch $)$-L;Port [\$378]:=Count+Latch;

End;

Begin

Keluar(1,L1); Keluar(4,L2);

End. 
Perangkat lunak dalam desain untuk pengontrolan gerak poros, akusisi data sudut dan intensitas, pengaturan arus end effector dan visualisasi layar monitor. Bahasa pemrograman yang digunakan yaitu Pascal. Struktur menu yang didesain Menu Utama terdiri atas submenu Auto dan submenu Manual serta Keluar. Submenu Manual berisi program yang akan mengatur tegangan untuk end effector dimana dalam pengaturan tegangannya menggunakan penekanan keyboard, tombol 1-9. Tombol 1-6 untuk gerak poros dan badan, tombol-7 untuk mengangkat beban dan untuk tombol 8 untuk mengubah arus. Sub menu manual ini pada prinsipnya berisi prosedur atau subrutin untuk menguji masing fungsi sub rangkaian. Dimana masing-masing subrutin tersebut adalah bagian untuk pemrograman auto. Pada menu Auto berisi program yang akan mengatur tegangan untuk end effector secara otomatis. Submenu dapat diisi beberapa rutin gerak untuk memindahkan beban, algoritma untuk 2 rutin gerak nya. Dalam menu auto ini, bila program dijalankan tranducer, gerak motor, pengubah arus akan bekerja secara otomatik. Sebagai contoh untuk memindahkan beban pada posisi-1 ke posisi-2, algoritmanya sebagai berikut:

\author{
Mulai \\ Tampil SubRutin-1; Gerakan ke pada posisi awal \\ Gerakan ke Posisi-1;Set arus Awal; Angkat beban \\ Ulang \\ Baca Kasus sensor cahaya \\ Mulai Kasus \\ Kasus Terangkat Mulai Pindahkan ke posisi-2 Selesai \\ Kasus Tidak terangkat \\ Mula Gerakan ke posisi-1;Ubah arus; Angkat beban Selesai \\ Selesai Kasus \\ Akhir Ulang pada posisi-2 \\ Selesai
}

Variabel tuntuk mengubah arus ada sebanyak 255 tingkatan. Arus tersebut akan meningkat secara bertahap. Proses terangkat akan dinyatakan dengan sensor akan meraba kondisi gelap dan sebaliknya.

\title{
4. Bahan Dan Alat dan Prosedur Pengujian
}

Untuk melaksanakan Program PKM ini diperlukan sarana dan peralatan dan bahan-bahan pwnyusun subrangkaian. Untuk peralatan meliputi Komputer IBM PC dan Compiler Pascal, Peralatan sumber sinyal (generator sinyal kompleks), Power suply standar (Catu daya), Osciloscope, Seperangkat alat kerja elektronik (Tollset), Alat ukur AVOmeter Analog dan Digital. Semua peralatan telah ada di laboratorium Instrumentasi. Untuk bahan-bahan dan komponen elektronik serta pengemasan konstruksi serta pendukung desain dianggarkan dalam PKM teridiri dari Konstruksi mekanik, transducer, Printed Circuit Board (PCB). Komponen elektronik: Resistor, kapasitor ,Opamp, ADC, DAC dan lainnya pendukung rangkaian.

Untuk menganalisa karakteristik linier masing-masing subrangkaian menggunakan korelasi dan regresi linier. Untuk persamaan korelasinya: 


$$
r=\frac{n\left(\sum x y\right)-\sum x-\sum y}{\left.\sqrt{\left[n \sum x^{2}-\left(\sum x\right)^{2} \llbracket n \sum y^{2}-\left(\sum y\right)^{2}\right.}\right]}
$$

Persamaan regresi linier $\mathrm{y}=\mathrm{m} \mathrm{x}+\mathrm{n}$. Dimana,

$$
\begin{aligned}
& m=\frac{N \sum\left(x_{i} y_{i}\right)-\sum x_{i} \sum y_{i}}{N \sum x_{i}^{2}-\left(\sum x_{i}\right)^{2}} \\
& n=\frac{\sum x_{i}^{2} \sum y_{i}-\sum x_{i} \sum\left(x_{i} y_{i}\right)}{N \sum x_{i}^{2}-\left(\sum x_{i}\right)^{2}}
\end{aligned}
$$

Dalam hal ini $\mathrm{n}$ adalah jumlah data, $\mathrm{x}$ adalah variabel bebas, $\mathrm{y}$ adalah varibel terikat.

Prosedur pengujian sub rangkaian meliputi Karakteristik hubungan Arus terhadap Beban terangkat, Transducer sudut dan Sernsor Cahaya, Sumber arus, Perantara (I/O), ADC, DAC, Driver motor. Untuk menguji perangkat lunak, sesuai dengan submenu yang dirancang. Terdidri atas pengujian untuk : pengaksesan perantara $(\mathrm{I} / \mathrm{O}), \mathrm{ADC}, \mathrm{DAC}$, dan program pengangkat beban pintar. Untuk menguji integrasi pada prototipe yaitu uji operasional pengangkat beban manual dan automatik.

\section{Hasil dan Diskusi}

Dalam melakukan kegiatan yaitu melaksanakan studi literatur dan pekerjaan yang meliputi pengadaan perangkat keras berikut perangkat lunaknya diperlukan jadwal Tiga bulan pertama untuk kegiatan per 2 minggu dikhususkan pada desain pencekram beban pinter meliputi perumusan elektromagnetik, konstruksi, rangkaian transducer, pengkondisi sinyal, perantara (I/O), ADC, DAC, Driver motor dan algoritma perangkat lunak Dua bulan kedua untuk kegiatan per 2 minggu melanjutkan sisa tiga bulan pertama dan pembuatan perangkat lunak untuk struktur menu dan penulisan laporan kemajuan. Dua bulan terakhir digunakan untuk membuat perbaikan, penyempurnaan dan pembuatan laporan akhir.

\subsection{Wujud Fisik}

Wujud fisik hasil rancang bangun terdiri atas: lengan dan box pengontrol yang ditunjukkan oleh Gambar 7. Pada ujung lengan terdapat solenoida yang berfungsi untuk mencekram beban yang akan diangkat. Pada ujung solenoida dilengkapi dengan sensor cahaya menggunakan LDR sebagai indikator beban yang tenagkat atau tidak terangkat. Pada box pengontrol terdapat perantara multiplexer yang dihubungkan pada I/O port parallel komputer dan tampak pada panel depan terdiri atas switch power dan LED. Untuk panel belakang terdiri atas, soket DB-25 untuk ke LPT dan kabel AC 220V.

\subsection{Kinerja Subsistem}

Dalam pasal ini antara lain dilakukan pengujian linieritas dari tranduser potensiometrik dan LDR, perantara ADC, akses I/O, beban terhadap tegangan 
pada solenoid, perantara DAC, penguat arus. Dalam pemrosesan data untuk hubungan linieritas menggunakan korelasi dan regresi linier dan korelasi.

1. Uji Rangkaian Tranduser Sudut, untuk mengetahui karakteristik linearitas tranduser sudut dengan potensiometrik. Pengukuran posisi sudut menggunakan busur derajat dan untuk tegangan menggunakan voltmeter digital dengan ketelitian $1 \mathrm{mVolt}$. Didapat persamaan linierinya adalah: $\mathrm{Y}=0.028 \mathrm{X}-0.0005$, dengan korelasinya $\mathrm{r}$ adalah 0.999 . Hal ini menunjukkan tranduser dan pengkondisi sinyal linier.

2. Uji Rangkaian LDR untuk mengetahui karakteristik beban terangkat dan atau tidak terangkat dengan LDR. Dalam hal ini keadaan gelap menyatakan beban terangkat, dengan kondisi keluaran tegangan (3-5) volt. Kondisi terang menyatakan beban tidak terangkat, dengan kndisi keluaran tegangan dibawah 3 volt. Pengukurannya menggunakan voltmeter digital dengan ketelitian 1 mVolt.

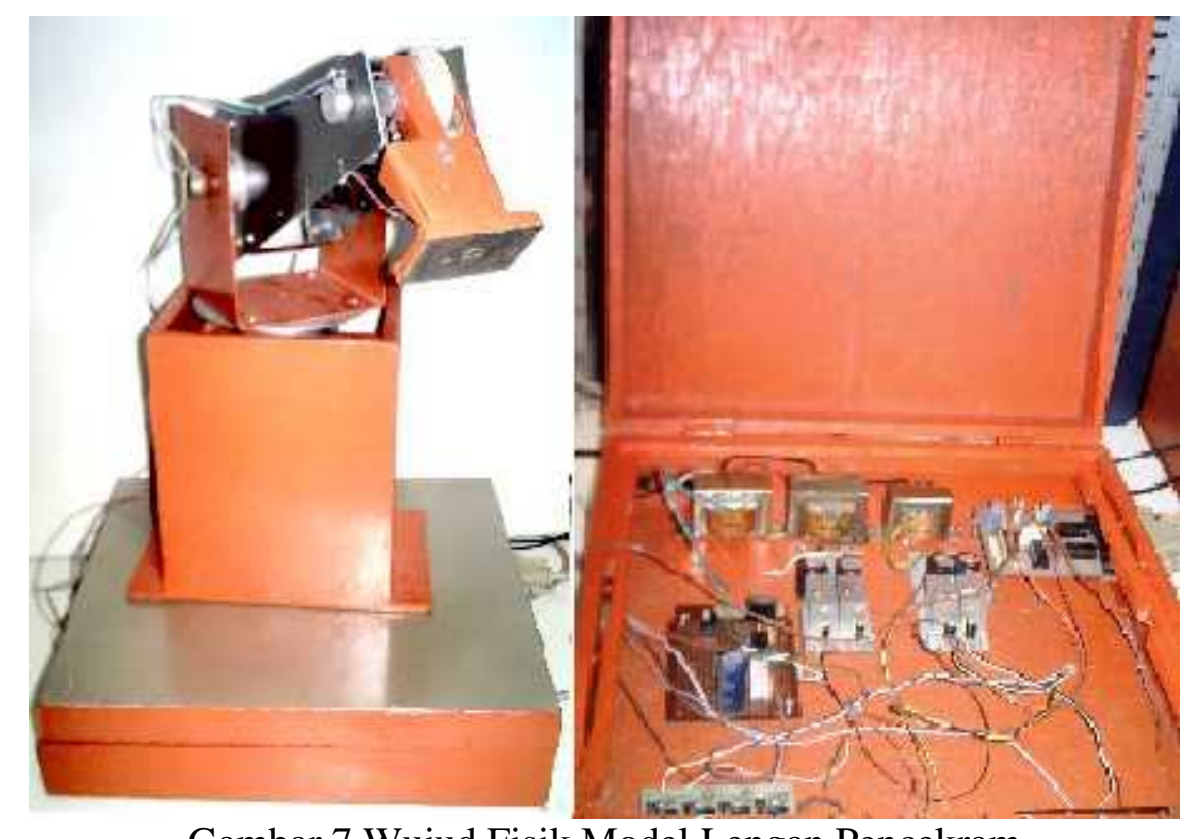

Gambar 7 Wujud Fisik Model Lengan Pencekram

Beban Pintar Metode Elektromagnetik

3. Uji Linearitas Perantara ADC, untuk mengetahui linearitas konversi analog ke digital pada proses pengukuran tegangan modus unipolar. Pengujian dilakukan dengan memasukkan besar sudut putaran pada masukan ADC, bersamaan diukur tegangannya dengan menggunakan voltmeter digital 3 digit dengan skala terkecil pada orde mVolt. Didapat linieritasnya Data $=364$ Derajat 7.277, Dengan korelasi r sebesar 0,999, harga ini menunjukkan ADC linier.

4. Uji Linearitas Perantara DAC untuk mengetahui linearitas konversi digital ke analog pada proses pengukuran tegangan modus unipolar. Pengujian dilakukan dengan memasukkan nilai data pada masukan DAC, bersamaan diukur tegangannya dengan menggunakan voltmeter digital 3 digit dengan skala terkecil pada orde $\mathrm{mVolt}$. Dengan cara regresi linier dan korelasi, persamaan $\mathrm{Y}$ $=\mathrm{mX}+\mathrm{n}$, untuk jumlah data 51 , didapat $\mathrm{m}=0.0196$ dan $\mathrm{n}=1.232$, sehingga 
linearitas data terhadap tegangan masukan DAC adalah $\mathrm{V}_{\mathrm{DAC}}=0.0196$ Data + 1.232 Dengan korelasi r sebesar 0,999, harga ini menunjukkan DAC linier.

5. Uji Penguat Tegangan untuk mengetahui linearitas penguat dari masukan DAC dimana keluarannya ke solenoida. Konversi tegangan akan menghasilkan medan magnet yang bervariasi. Pengujian dilakukan dengan memasukkan data dari komputer/PC dan keluarannya diukur dengan menggunakan voltmeter digital 3 digit dengan skala terkecil pada orde mVolt. Dengan cara regresi linier dan korelasi, persamaan $\mathrm{V}_{\mathrm{o}}=\mathrm{mV}_{\mathrm{i}}+\mathrm{n}$, untuk jumlah data 51, didapat $\mathrm{m}=$ 3.99 dan $\mathrm{n}=-1 \times 10^{-4}$, sehingga linearitas data terhadap tegangan masukan ADC adalah $\mathrm{V}_{\mathrm{o}}=3.99 \mathrm{Vi}-1 \times 10^{-4}$ dengan korelasi $\mathrm{r}$ sebesar 0,999, harga ini menunjukkan penguat linier.

6. Uji Perantara I/O dan Integrasi, dalam hal ini menguji akses (I/O) dan ADCparalel dengan metode Pencacah dan Latch serta integrasi . Pengujian dengan menggunakan prosedur Pascal. Sesuai prosedur Keluar(L,data). Pengujian kode binner menggunakan 8-LED, dimana pengkodean nyala dengan logika 1 dan padam logika 0. Dalam implementasi L1 keluar pada Latch1 yang akan digunakan untuk dua motor, dimana keluar (L1,0) semua motor tidak berputar. Untuk motor-1 gerak ke kanan keluar $(\mathrm{L} 1,1)$, arah gerak ke kiri keluar $(\mathrm{L} 1,2)$. Untuk motor-2 gerak ke atas keluar $(\mathrm{L} 1,4)$ dan arah bawah keluar $(\mathrm{L} 1,8)$. Untuk L2 digunakan untuk kode binner DAC. Selain pengujian dengan menggunakan LED, masing-masing LED juga dihubungkan ke driver dua motor dan DAC. Dari hasil uji I/O metode Pencacah-Latch berjalan sesuai dengan desain.

7. Pengujian Beban Terhadap Tegangan pada Solenoid untuk menguji sumber magnetik pada solenoid sesuai dengan Hukum Biot-Savart sebagai sumber arus dari keluaran penguat tegangan, dengan parameter rancanga kontruksi pencekram yang dengan memisalkan $\alpha=1000$ Maka didapat hubungan berat terhadap Arus yaitu, Berat $=0.11109$ I (Berat dalam grm, I dalam Ampere). Untuk menentukan kinerja suatu alat berfungsi dengan baik, maka perlu dilakukan uji linearitas, dalam hal ini bertujuan agar arus yang digunakan untuk menghasilkan medan magnet, dimana pada penelitian ini digunakan untuk mengangkat suatu beban yang memiliki massa tertentu. Dikarenakan pengujian arus (I) terhadap medan magnet (B) tidak dapat diterapkan, dan hanya paramater nilai arus yang menjadi nilai yang dicari (output) terhadap massa beban yang terangkat (input),dengan demikian diperoleh persamaan untuk uji linearitasnya. $Y=111,09 X+0,0011$ (Y dalam gram $\mathrm{X}$ Dalam Ampere). Dengan persamaan ini untuk kebutuhan arus untuk setiap beban dapat ditentukan.

\subsection{Pengoperasian}

Untuk mengoperasikan pencekram beban pintar metode elektromagnetik berbasis IBM PC, pertama-tama sambungkan semua kabel pada slot yang telah ditentukan. Hidupkan box, hidupkan komputer, lalu jalankan program Cekram.EXE. Saat program dijalankan maka akan tampil program menu utama dengan logo dan menu pilihan: manual 1, manual 2, dan auto, dan keluar. Bila memilih submenu manual 1, maka pada layar monitor akan tampil frame skala sudut dan instruksi tombol untuk menggerakkan masing-masing motor-1 dan motor-2. Menu ini 
berfungsi untuk menggerakkan lengan secara manual dengan menekan tomboltombol yang telah ditentukan. Bila memilih submenu manual 2, maka pada layar monitor akan tampil frame skala sudut dan instruksi tombol untuk menggerakkan motor-1 dan motor-2 secara bersamaan. Menu ini berfungsi untuk menggerakkan lengan secara manual dengan menekan tombol-tombol yang telah ditentukan, dimana penggunaan tombol adalah sebagai berikut: Bila memilih submenu auto, maka pada layar monitor akan tampil sesuai frame skala sudut dan pilihan auto untuk auto-1 memindahkan empat progam menangkat dan memindahkan benda. Bila memilih submenu Keluar maka akan keluar dari program, atau dapat juga menekan "Esc" pada keyboard dan akan langsung kembali pada tampilan windows.

\section{Kesimpulan}

Telah dirancang model pencekram beban pintar metode elektromagnetik berbasis IBM-PC. Spesifikasi perangkat keras dirancang menggunakan tranduser sudut dengan menggunakan potensiometrik dan sensor cahaya menggunakan LDR sebagai indikator beban yang terangkat dan tidak terangkat, dengan akusisi data ADC digunakan Max 195 - 16Bit, dan DAC 0808 - 8bit diset pada modus unipolar dengan referensi $(0,+5)$ Volt. Pengaksesan melalui Port LPT IBM-PC, perangkat lunak disusun terdiri dari submenu manual 1, submenu manual 2 dan submenu auto untuk mengetahui keadaan beban terangkat atau tidak teaangkat dengan bahasa pemrograman Pascal.

Dari kinerja perangkat lunak saat ini pengoperasian masih menggunakan tombol manual, hal ini dikarenakan masih menggunakan bahasa pemrograman Pascal yang dioperasikan dengan modus standar grafik. Bila ingin dijalin pada OS.Windows, dalam hal ini dapat digunakan bahasa pemrograman Delphi dengan fasilitas Multitasking Sampel yang bergerak dan dapat dipantau pada layar monitor, dengan akses penggerakan dapat menggunakan 'Clik' Mouse.

Peraba pada pengangkat beban untuk terangkat dan tidak terangkat masih menggunakan dua keadaan (terang-gelap) dan sensor yang digunakan masih sangat sederhana, yaitu menggunakan LDR yang sensitivitas dan akurasi sensornya tidak telalu baik. Untuk hasil yang lebih teliti, sensor keadaan teranggelap dapat menggunakan sensor visual misalnya dengan kamera CCD, sehingga seolah-olah pencekram melihat beban yang akan diangkat/diambilnya. Juga untuk ketelitian pada keadaan beban terangkat atau tidaknya dapat menggunakan sensor kekuatan seperti sensor daya tekan (strain gauge) yang dapat mengukur perubahan resistansi suatu logam, sehingga dapat menunjukkan kekuatan genggaman gripper, sedangkan sensor sentuh untuk mendeteksi apakah benda telah disentuh gripper atau tidak, sehingga akan didapatkan nilai/besar berat beban tertentu yang lebih akurat yang akan terangkat atau tidak oleh pencekram. 


\section{DAFTAR PUSTAKA}

1. J. Harstein D Sharon. Robot dan Otomasi Industri, Jakarta. : PT. Elex Media Komputindo. 1992.

2. 1.R.S Fu,R.C Gonzales,C.S.G Lee,Robotic Mc.Graw Hill, Book Co 1990.

3. A.P Malvino, Digital Principle And Application, Mc.Graw Hill,1990.

4. Link, Wolfgang. Pengukuran Pengendalian dan Pengaturan dengan PC. Terjemahan Gramedia. 1993.

5. J.W.Conffron, The IBM Connection, Sybex 1980.

6. S.E Derenzo, Interfacing, Prentice Hall,1990

7. W.D Coopper, Electronic Instrumentation Measurement Tehcnique, 4th Prentice Hall Inc Englewood Cliff N.Y. USA 1990. 